\title{
Developing a Vision for Teacher Education Programmes: A Values-based Approach
}

\section{RONALD G. SULTANA}

SUMMARY This article presents one approach to the development of initial teacher education programmes that are based on a vision, premissed on values shared consensually by faculty staff and students. The article first provides a brief historical background of the Faculty of Education at the University of Malta, where this values-based approach was attempted. It addresses some of the key problems faced in the development of a coherent and organic course of studies with students following graduate and post-graduate courses, and gives an account of the way some of these problems were addressed. It is claimed that the approach adopted at the University of Malta can help other teacher educators in clarifying objectives as they set out to create coherent programmes that provide a sense of mission based on identifiable values and principles.

RESUMÉ Cet article présente une approche pour le développement de programmes de formation initiale des enseignants basés sur une vision qui a, comme principe, des valeurs partagées en consensus par le personnel de la faculté et les étudiants. Cet article fournit tout d'abord un bref contexte historique de la Faculté d'Education a l'Université de Malte, ou cette approche basée sur des valeurs a été tentée. Il aborde quelques uns des problemès-clef auxquels on est confronté dans le développment d'un prgoramme d'études cohérent et systematique avec des étudiants de licence et au delà, et il expose la façon dont certains problèmes ont été abordés. Cet article revendique le fait que l'approche adoptée a l'Université de Malte peut aider d'autres éducateurs de futurs enseignants à clarifier des objectifs alors qu'il se preparent à creér des programmes cohérents qui apportent un sens de mission basé sur des principes et des valeurs identifiables.

RESUMEN Este articulo presenta un enfoque para el desarrollo de los programas de formación inicial para los profesores, basados sobre una visión que tiene, como principio, el consenso de los valores compartidos entre el personal de la facultad y los estudiantes. este articulo presenta en primer lugar un breve contexto histórico de la Facultad de Educación de la Universidad de Malta, donde ha tenido lugar este enfoque basado sobre los valores. Trata algunos de los problemas clave con los que nos encontramos en el desarrollo de un programa de estudios coherente y sistemático con estudiantes de licenciatura o de grado superior, y expone de que manera algunos de ellos han sido tratados. Este articulo reivindica el hecho de que el enfoque adoptado por la Universidad de Malta puede ayudar a otros formadores de futuros formadores a poner en claro los objetivos al prepararse para la creación de programas coherentes que dan un sentido de misión basado sobre los principios y los valores. 


\section{European fournal of Teacher Education}

Zusammenfassung Dieser Beitrag präsentiert einen Ansatz für die Entwicklung von Lehrerausbildungsprogrammen auf der Basis einer Vision, die sich auf gemeinsame Werte von Lehrenden und Lerrnenden stützt. Der Beitrag gibt zuerst einen kurzen historischen Uberblick über die erziehungswissenschaftlischen Fakultät an der Universität Malta, wo dieser Werte orientierte Ansatz entwickelt wurde. Es werden einige Schlüsselprobleme behandelt, die bei der Entwicklung eines organischen und stimmigen Studienganges entstehen, und es wird berichtet, wie einige dieser Probleme behandelt wurden. Dieser Ansatz der Universität Malta soll anderen Lehrerausbildem, die stimmige, sie auf bestimmte Werte und Prinzipien stützende Programme entwickeln wollen, bei die Klärung ihrer Ziele helfen.

\section{Introduction}

The Faculty of Education at the University of Malta [1] was set up in 1978, and since then has catered for an average of 100 undergraduate students for each of its 4-year groups and, more recently, for an average of 35 PGCE students annually. Students following the 4-year honours degree course typically specialise in two content areas, such as the teaching of a language and the teaching of children in their early and middle years, or Physics and Chemistry for instance. Courses in educational theory and foundation disciplines as well as block teaching practice sessions are compulsory for all students, while a number of optional courses are offered during the third and final years. All students are required to submit a 15000 word dissertation, related to an educational topic or concern. The Faculty's one year PGCE courses stress pedagogy and methodology, with an attempt to link educational theory and practice through the "Situations and Themes" approach pioneered at Cambridge University (Hirst, 1991; Sultana, 1991). A key feature of the teaching practice component of all courses is the negotiation of a close relationship with schools and teachers, especially through the "mentoring scheme" which has recently been adopted by staff. The Faculty of Education provides the only University-recognised teacher training on the island, though the State's Department of Education does offer "P.G.C.E." courses and training for kindergarten assistants as an interim measure and in response to teacher shortage.

The Faculty of Education-with departments of psychology, foundations in education, arts and languages in education, mathematics, science and technical education, primary education, and communications and instructional technology-also runs a number of part-time, evening certificate and diploma level courses, including, among others, a Diploma in School Counselling, a Diploma in Adult Education, and a Diploma in Educational Administration and Management. It also runs a Masters in Education course, which puts a stress on educational theory, and has a growing number of doctoral candidates. Among the research interests and foci of the thirty-odd staff, one could mention projects related to children with special learning needs (Tanti Burlo', 1992), sociology of educational inequality, with special reference to vocational education (Sultana, 1992a), life-long and adult education (Wain, 1987; Mayo, 1994), science and environmental education (Ventura, 1992), education in small states (Farrugia \& Attard, 1989), curriculum theory (Fenech, 1992), teachers' stress (Borg \& Riding, 1991), and policy-making (Darmanin, 1991). Two programmes have been set up over the past 2 years, one related to doing philosophy with children, the other 
to comparative education, with a special focus on southern Europe and the Mediterranean region. One innovative venture which involved students and staff alike was the setting up of a University-based, reform-minded pressure group, the Moviment Edukazzjoni Umana (Movement for Humanistic Education), which sets out to introduce progressive agendas and practices in schools on the island (cf. Sultana, 1992b). Its most recent activity was the launching of a Charter of Students' Rights, an initiative which attracted much local and some foreign media attention and which received the approbation of hundreds of students and parents, as well as of some politicians (cf. Spiteri, 1994).

Graduate and post-graduate courses at the Faculty are run on a "unit" (15 hours' lectures with a specific focus) and "module" (a set of a number of inter-related units) basis, and while this gives a degree of flexibility to the whole programme on offer, it has also generally led to complaints-on the part of students and lecturers alike-that the different parts of the course do not come together sufficiently strongly, to the detriment of coherence at the level of theory, and of organic linkage at the level of theory and practice. This tendency has been reinforced by the incremental nature of the whole programme, with young staff joining the Faculty, bringing with them new theories and approaches which were often appended to the Faculty's curriculum rather than confronted so that the "old" and the "new" could stimulate each other in a dialectical manner.

This rift between the old and the new emerged not only in the substantive content of the courses offered, but perhaps more importantly in the approach to the vision for the whole programme of initial teacher education. Senior members of staff had generally come up through the ranks as teachers in schools, and then as tutors in training colleges, where the "academic tradition", as it will be referred to below, while important, was only valued to the extent that it had direct relevance to the improvement of classroom practice. "Younger" members of staff, who became teacher educators when the two Training Colleges--set up in the early forties-were dissolved and the Faculty of Education set up, found themselves working in an environment which gave priority to academic research, publications, and lecturing based on foundational disciplines. This tension between theory and practice, between a conception of teacher-asscholar and teacher-as-artisan/pragmatist, has been experienced by many teacher trainers as initial teacher education programmes have increasingly been organised within universities (Ryba, 1992; Neave, 1992). That tension need not necessarily be considered negatively-it has, for instance, given birth to a number of interesting tools and concepts with which to approach the task of teaching, foremost among these being the idea of the "reflective practitioner" (Schön, 1983) and more recently, "mentoring" (Wilkin, 1992), both of which have much currency in our Faculty at the present moment. But it is also true that dialectic has not been easily resolved or transcended, and that staff and students at the Faculty of Education in Malta and, I am certain, elsewhere, are constantly pressed to address these crucial concerns, and to ensure that academicisation does not trade in pedagogy for status (cf. Wubbels, 1992, p. 162).

\section{Key Concerns}

One forum where staff address such key concerns consists of an annual two day seminar, where students give staff feedback on their experience as learners throughout 


\section{European fournal of Teacher Education}

the course, and as novice teachers following block teaching practice or/and their first year of teaching. As indicated earlier, one recurrent problem has been the overall coherence of the programme on offer, and while some of the issues raised at the annual seminar and throughout the year required a technical, administrative solution, others seemed to have connection with deeper, normative concerns. Thus, such problems as the overlapping of material and repetition of the same ideas between one unit and another could be addressed relatively easily through the distribution of all course descriptions to faculty staff, and through better co-ordination. Much more challenging were critiques, raised by staff and students alike, that the course as it was currently organised occasionally covertly contradicted the kinds of practices students were overtly being encouraged to adopt in schools and classrooms.

In view of these and other challenges Faculty staff and representatives from the student body set out to "return to the drawing-board", as it were, and to ask two very basic questions:

(a) What is a "good teacher"? and

(b) What kind of course will facilitate the development of such a teacher?

The premise underlying such a discussion was that it would lead to a clarification of values, and that it was only after staff came to grips with a common vision that a coherent and focused "mission" would emerge. Staff would reveal their passions, values and justifications:

... to reveal and justify from [our] own viewpoints what [we] believe and value

... to transcend the limitations and restrictions of [our] social conditioning and common sense and to venture beyond by seeing and changing new possibilities" (MacDonald, 1988, p. 163, cited in Smyth, 1991, p. 72).

In this context, therefore, "values" and "value systems" refer to:

... an enduring organisation of beliefs concerning preferable modes of conduct or end-states of existence along a continuum of relative importance" (Rokeach, 1973, p. 5, quoted in Abela, 1991, p. 27).

Values therefore have a motivational component, since they lead to the choice from among alternatives, and help resolve conflicts and decision-making.

The group discussions and seminars organised around the two questions (a) and (b) above were open-ended, and brain-storming was used as the key facilitative strategy. The role of the present author was to note the ideas expressed, draw linkages between the various proposals in such a way that the underlying values became more clearly visible, and to place the results of the discussion within a theoretical context which transcended substantive issues and which provided a framework for future discussion and critical evaluation and programme design.

For the sake of this paper I have opted to reverse the order of presentation of what transpired in the process of discussion, and of what I am referring to as a "values-based approach to initial education programme planning". I will therefore first present four key traditions that inspire, in different ways, initial teacher education programmes. This will help us place discussions about "the good teacher" and "the course that will facilitate the development of such a teacher" in perspective. I will then outline the key qualities of "a good teacher" as developed during the group work at the seminar. The values implicit in this particular conceptualisation of the good teacher are teased out. 
Finally, the self-reflective exercise concludes by considering the implications of these conceptions of good teaching and the adherence to a specific value-system for the facilitation of a coherent identity in our initial teacher training programmes.

\section{Four Traditions in Initial Teacher Education}

Various scholars and researchers have identified a number of traditions guiding the development of preservice teacher education programmes. The work of Kemmis et al. (1983), Smyth (1991), and Howey and Zimpher (1989), among many others, seems to draw from the threefold schema of knowledge interests developed by Habermas (1971) in order to suggest that our images of schooling and of education can be informed by a technocratic, by a hermeneutic, or by an emancipatory rationality. In our approach to schooling and education, we can therefore stress a means-ends, utilitarian, reproductive dimension, a personalist, humanist, open-ended and interpretative approach, or a more politically informed and transformative commitment.

It would be instructive to consider briefly the ways such rationalities have inspired traditions of initial teacher education before moving on to an analysis of what constitutes good teaching and good teacher training. Liston and Zeichner (1993) identify four such traditions which, while discussed with reference to the north American context, are equally applicable to the European one. The "academic tradition" developed mainly following the attempt to establish education as a university discipline in its own right, and to have equal status with other faculties. It therefore emphasised the teaching of foundation disciplines, and treated the teacher more as a scholar and a subject specialist rather than as a pedagogue. In this case, it is more important to know Mathematics (the subject) than to know Mary and John (the students) in order to be considered a "good teacher". It is this tradition which has has hitherto characterised secondary school teachers in France, for instance-at least up till the introduction of the Instituts Universitaires de Formation des Maitres (I.U.F.M.) in 1989. The "social efficiency tradition" of teacher education is closely associated to the technocratic rationality identified by Habermas, and its hallmark is a faith in the scientific study of education and application of results of such study. It entails a comprehensive description of duties and traits of teachers and building a programme on that, and hence is competency and performance based. The emphasis is on specific skill training through such programmes as microteaching, microcomputer and other simulations and teacher training packages, with the "good teacher" being the one who is capable of applying a knowledge base which has been specified in advance. It is the "how to" rather than the "why" questions which predominate in this approach, and at its worst, this tradition gives rise to teacher-proof teaching packages, so eloquently criticised by Apple (1986). It is this tradition which seems to predominate in a number of western-type democracies at the present historical conjuncture (Smyth, 1991).

A third tradition which Liston and Zeichner identify is what they call the "developmentalist tradition", or, as it has been referred to by others, the "personalist" or "humanist" tradition. Closely related to Habermas' notion of hermeneutic rationality, this tradition of teacher training departs from a vision of education that places priority on the needs of the learner and his/her development. Here, the "good teacher" knows John and Mary at least as much as she knows Maths. Inspired by the child study movement, this approach highlights the necessity of providing supportive and stimulat- 
ing learning environments. The corresponding image of the teacher is that of a person who is fully alive, and who, rather than mechanically applying skills, is-rather more like an artist, naturalist and researcher-involved in facilitating the growth of the learner through such expressive techniques as dance, creative dynamics, writing, painting, storytelling, and so on. The good teacher is, in this tradition, the one who is capable of responding to students' current understandings and developmental readiness, so that learning is seen as emerging out of personal relationship through constructivist approaches.

A fourth tradition is the "social reconstructionist" or transformative one, aligned to Habermas' notion of emancipatory rationality. In this approach to teacher education the focus is on teachers' abilities to see social and political implications of actions. There is an understanding of education as a means of promoting a more humane and just society, so that the key image is transformation, not reproduction of society. Teacher education programmes inspired by this tradition are likely to adopt a political agenda which includes positive discrimination in favour of the poor and the disadvantaged by the system, and are particularly sensitive to the needs of learners who come from the working class, from ethnic and racial minorities, who suffer from disabilities, and who are girls.

The implications of these traditions of teacher education, and the images or visions of education they carry with them, are important, and have been elaborated upon in different ways by Kemmis (1984) and Codd (1985) among others. The former author seems to suggest that particular programmes fall rather narrowly into one of the traditions they identify, while Musgrave (1984), Liston and Zeichner (1991), and Zeichner (1993) suggest that in fact any educational project, including initial teacher education programmes, necessarily engage all of the above-mentioned rationalities, though a particular programme develops its identity when it emphasises one or more of these traditions over others. The traditions can therefore be considered to be akin to Weber's heuristic device, which he referred to as "ideal types".

\section{Developing a Faculty Identity: A Values-based Approach}

The above framework helps to confront more systematically the material which emerged from the staff seminar and subsequent discussions related to the dynamic definition of the "good teacher" and to a programme which facilitates the development of such a teacher. A number of personal, professional and intellectual qualities were mentioned by staff, and when these were analysed by the present author, it became clear that a relatively coherent set of values were underpinning the whole debate, and that once these were articulated, such values pointed towards a specific form and identity for the overall teacher education programme. In other words, it became rather clear that the Faculty identity drew its main inspirations from the "developmentalist" and, to a lesser extent, the "social reconstructionist" traditions identified above. This was confirmed when the present author carried out an item analysis of 180 reports written by staff members when they evaluated students' performance during teaching practice. The key items appear in Table I below, and are a powerful indicator of what staff value in terms of effectiveness in teaching. Starred items represent qualities most frequently mentioned.

Let us now look at the descriptors used by Faculty staff in their attempt to identify the "good teacher", as articulated during different staff seminars and debates. The values implied in such descriptors are teased out, as are the implications for a reformed 
TABLE I. List of categories used by Faculty staff in evaluating students during their teaching practice.

\begin{tabular}{ll} 
Student-teacher qualities & \\
\hline Level of commitment* & Rapport with students \\
Ability to manage class & Rewards pupils \\
Preparation of lessons & Willing to learn \\
Professionalism & Self-evaluation \\
Understands/sensitive to students & Critical/reflective \\
Open to pupils' experiences & Challenging \\
Patiently elicits knowledge & Enthusiastic \\
Keen to innovate & Confident \\
Relaxed/patient &
\end{tabular}

General classroom atmosphere

\begin{tabular}{ll}
\hline $\begin{array}{l}\text { Relaxed/friendly atmosphere } \\
\text { Class control/management }\end{array}$ & $\begin{array}{l}\text { Too boisterous } \\
\text { Seating arrangements }\end{array}$ \\
\hline General Pedagogy & \\
\hline
\end{tabular}

Active learning/discovery learning mode* Eye-contact*

Use of audio-visual aids* Questioning techniques*

Discussion methods used

Teacher-centred delivery

Tempo of speech

Preparation of teaching file*

Material suitable for age group ${ }^{\star}$

Conclusion of lesson

Remains in teachers' territory

Dialogue/participation ${ }^{\star}$

Careful follow-up to lesson

Relates to students' experiences

Sequencing of parts of lessons

Allows students to make mistakes

Talks/explains too much
Facial expressions

Use of group work ${ }^{\star}$

Clear instructions

Introducing lesson*

Posture

Use of resources*

Able to motivate

Passive students

Voice quality

Deviation from plan

Blackboard work ${ }^{\star}$

Vague goals/objectives

Pacing of delivery

Flowing presentation

Waste of time

Handling mixed ability

Includes all students

\section{Subject Methodology}

Intelligent use of textbooks

Balance between oral/written work

Use of Maltese and English as medium*
Mastery of content

Use Maltese context

teacher education programme which, building on elements incrementally introduced over the years, could now systematically pursue a coherent set of principles based on a clearly articulated educational vision. The teacher qualities, values, and course implications are presented systematically below, and are summarised graphically in Table II. There are, necessarily, connections between each of the sections outlined, but differentiation is maintained for heuristic reasons.

1. A good teacher must have a set of core personal qualities which facilitate interaction with the learner and promote the educational enterprise. Among these are empathy, commitment, caring, warmth, moral courage, humour, genuineness, and an openness 
to the process of growth. These qualities should be informed by an understanding of the context in which they are exercised-such a professional awareness ensures that learning goals, for instance, are not sacrificed for the sake of being liked by students.

Value implicit: The key resource is the teacher herself.

Implications for course: The sustained and planned development of "self" is the focus of the course. This should happen both through formal curricula (e.g. courses in sensitivity training, growth groups, and so on), and informal curricula, (that is, through the socialisation experience provided by the Faculty).

2. A good teacher is mainly concerned about learners, and has an ability to understand their different abilities, experiences, needs, as well as an ability to assess, diagnose, and respond to these needs. She is adaptable, and is ready to move outside one specific role in order to respond to learners' needs. A good teacher educates, teaches, counsels, assesses, administers, innovates.

Value implicit: An educational enterprise which values students' experiences/knowledge/interests/voice.

Implications for course: Small group tutorial/seminar teaching methods should be preferred over others. Learning relationships between staff and students to be facilitated by the assignment of small groups of students to a study tutor from faculty staff. Specialist rather than generalist training would better prepare teachers to respond to specific needs of learners.

3. A good teacher has a core of professional skills, a sophisticated knowledge base which includes, but goes beyond content to the effective transmission of that content. This knowledge base would include knowledge of educational aims, of subject matter, of learners, of curriculum, of pedagogy.

Value implicit: Excellence.

Implications for course: The identification of such a knowledge base which is sensitive to the local cultural, political and educational realities. This would be followed up by the development of a strong co-ordination between courses to ensure that this knowledge base is communicated effectively and that inter-course connections are established.

4. A good teacher is a reflective practitioner, one who reflects inwardly-to address issues related to classroom practices, methodology, etc.-and outwardly-considering the interaction between what she does in the classroom and the social context in which that educational endeavour is framed. She is thus aware of the social and political implications of actions developed in the microcosm of the classroom, and has the moral courage to be critical and develop alternatives to the forms of life generated within schools and outside of them.

Values implicit: Macro and micro knowledge is interwoven. Knowledge production is valued over knowledge consumption.

Implications for course: There is a focus on exploring and problematising knowledge held by students in common sense ways. This is enhanced by a systematic effort to expose learners to multiple perspectives, so that students would be better able to consider the social and political dimensions of teaching. Reflection is treated as social practice, not a private activity. There is an emphasis on an understanding of the historical embeddedness of our contemporary activity. Theoretical models are presented to students so that they may deconstruct and reconstruct knowledge in an active and critical manner. Investigative, research-based projects in classrooms and communities are preferred over traditional essay-type assignments. Introductory courses on 
learning how to learn will further facilitate the task of students taking over their own learning.

5. A good teacher privileges both theory and practice, and sees the link between frameworks of thought and the contexts of their application, between content and method, goals and processes of education. She is thus a leader in school and public communities.

Values implicit: Organic link between theory and practice. A view of knowledge which entails responsibility to self and community.

Implications for course: Team and inter-disciplinary teaching to be encouraged. Journal writing and ethnographic as well as case study material to be discussed/ analysed. Experiential teaching/learning mode to be given a priority. Courses to be based on research highlighting local situation. The course should help student-teachers develop skills in curriculum development, in school and community leadership, in evaluating school programmes and in implementing change. The Faculty should itself be a leader at the University and in the community in the field of education. It should develop educational outreach services to the community, and have close links with local councils and school councils.

6. A good teacher is aware of the context she will work in as a professional. This includes knowledge of the way the educational system functions, of education acts, national curricula, codes of ethics, union affairs, and so on. A good teacher is aware of how "the system" will translate into demands which will sometimes contradict values and positions held, and will know how to creatively handle and resolve, where possible, the ensuing tensions between ideals and reality.

Values implicit: Idealism forged in the crucible of reality.

Implications for course: Relevant information with regards the local educational system should be passed on to students in a critical manner. There should be an involvement with practitioners (including teachers, policy-makers) to inculcate appreciation of constraints and political/power agendas in the running of an educational system, and how to work with/against these. There should be an induction programme for beginning teachers to ease them into the profession and guard against institutional/ ideological incorporation.

7. A good teacher is moral, and driven by a sense of mission. Teaching is thus seen by such teachers as a value-laden activity. This is not a mission, however, where the goal is to "convert the barbarians" to an educational culture, but a mission which reaches out to dialogue with others for the sake of mutual growth. If education is understood as empowering, then the key focus of our energy should be on those who are, in some way or other, disempowered.

Values implicit: Option in favour of disadvantaged and non-achieving. Teaching is a profession in the sense that it is an activity directed toward service aimed to some valued end, some public good.

Implications for course: All students experience at least one teaching practice in a school or classroom catering for students with special learning needs. Faculty research focuses on students with learning difficulties, and gives them a priority in terms of attention. The Faculty could also induce students into the course it offers, so that staff can communicate their value systems, identify their sense of mission, and their commitment to model, through their interaction with students, the personal and professional qualities deemed essential to good teaching.

This is based on the understanding that, if there is to be complementarity between campus and field experiences, then course programmes need to be negotiated with, and 
TABLE II.

Type of teacher Values Implications

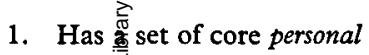
qualities

learning

empathy, commitment, caring, warmth, moral courage,

humour)

2. Is mầnly concerned about learners, ofind has an ability

to respon effectively to

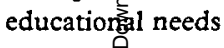

\section{Has a core of}

professional skills, a

sophisticated knowledge base

which includes, but goes

beyond content to the

effective transmission of

that content

4. A good teacher is a reflective practitioner, one who reflects inwardly and outwardly

5. Privileges both theory and practice, and sees the link between frameworks of thought and the contexts of their application. Is a leader in school and public communities

Implications

Sustained and planned development of "self" is focus of the course through formal curricula (e.g. sensitivity training, growth groups, etc.), and informal curricula (i.e. the socialisation experience provided by the Faculty)

Values students' experiences

knowledge

Excellence

Key resource: the teacher

knowledge is

interwoven;

knowledge production

Knowledge entails responsibility to self and community
Small group tutorial/seminar teaching methods preferred over others

Each student or small group of students is assigned a study tutor from faculty staff

Developing an adaptable teacher, but also a specialist

The identification of such a knowledge base

Strong co-ordination between courses to ensure that this knowledge base is communicated effectively and that inter-course connections are established.

Focus on exploring and problematising knowledge held by students in common sense ways

Exposure to multiple perspectives

Able to consider social and political dimensions of teaching

Reflection treated as social practice, not private activity Research-based assignments

Team and inter-disciplinary teaching to be encouraged Experiential teaching/learning mode to be given a priority Courses based on research reporting Maltese situation

Teachers ought to have skills in curriculum development, and in school and community leadership

Faculty as a leader 
TABLE II. Continued

\begin{tabular}{|c|c|c|}
\hline Type of te & Values & Implications \\
\hline 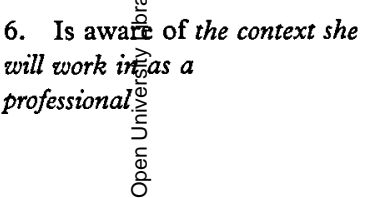 & $\begin{array}{l}\text { Idealism forged in } \\
\text { the crucible of } \\
\text { reality }\end{array}$ & $\begin{array}{l}\text { Relevant information with reference to the Maltese educational } \\
\text { system } \\
\text { Involvement with practitioners to inculcate appreciation of } \\
\text { constraints and political/power agendas in the running of an } \\
\text { educational system, and how to work with/against these }\end{array}$ \\
\hline $\begin{array}{l}\text { 7. Is morath and driven by a } \\
\text { sense of mision. Teaching is } \\
\text { thus seen buch teachers as } \\
\text { a value-laden activity }\end{array}$ & $\begin{array}{l}\text { Option in favour of } \\
\text { disadvantaged and } \\
\text { non-achieving }\end{array}$ & $\begin{array}{l}\text { All students experience at least one teaching practice } \\
\text { with disadvantaged students } \\
\text { Faculty research focuses on students with learning difficulties } \\
\text { Faculty out to promote complementarity between campus and } \\
\text { field experiences }\end{array}$ \\
\hline $\begin{array}{l}\text { 8. Actively seeks continuous } \\
\text { professional development }\end{array}$ & $\begin{array}{l}\text { Excellence; } \\
\text { sustained } \\
\text { commitment }\end{array}$ & $\begin{array}{l}\text { Clear messages to be given regarding need for continuous } \\
\text { development } \\
\text { In-service training becomes a compulsory requisite for the } \\
\text { continued accreditation of teachers }\end{array}$ \\
\hline $\begin{array}{l}\text { 9. A good teacher is so in } \\
\text { the context of the classroom } \\
\text { and school. It is in the } \\
\text { practice of teaching that } \\
\text { excellence manifests itself }\end{array}$ & $\begin{array}{l}\text { Practicing teachers } \\
\text { have their own } \\
\text { expertise to } \\
\text { contribute }\end{array}$ & $\begin{array}{l}\text { Teaching practice is the key to the development of those } \\
\text { personal and professional qualities and skills identified } \\
\text { above teaching practice to be seen as a collaborative } \\
\text { venture between Faculty staff, students, and school-based } \\
\text { professionals, and hence mentoring be adopted as a key } \\
\text { policy of our faculty }\end{array}$ \\
\hline
\end{tabular}


evaluated by, students. Social relations between staff, and staff and students should also by characterised by democratic rather than hierarchical values, and this entails the acceptance of the principle of accountability. There should therefore be a systematic framework for overall evaluation.

8. A good teacher actively seeks continuous professional development.

Values implicit: Excellence and sustained commitment.

Implications for course: Clear messages to be given regarding need for continuous development. This should be strengthened by negotiating the principle that, as in such countries as Belgium, France, Spain, in-service training becomes a compulsory requisite for the continued accreditation of teachers.

9. Ultimately, a good teacher is so in the context of the classroom and school. It is in the practice of teaching that excellence manifests itself.

Value implicit: Practicing teachers have their own expertise to contribute.

Implications for course: Teaching practice is to be considered the key to the development of those personal and professional qualities and skills identified above. It is to be seen as a collaborative venture between Faculty staff, students, and school-based professionals, and hence the practice of school mentoring, with its recognition of the particular situational expertise of teachers, ought to be adopted as a key policy of the faculty. The link between attitudes, knowledge, skills, values and competencies should emerge in the classrooms and schools, and staff have to be there as a team to respond to students' current understandings and developmental readiness. Inter-disciplinary collaborative feedback to students requires the formation of staff teams who develop a professional working relationship, with clear goals and a readiness to become involved in and with schools. Students are thus assessed by a team of professionals and in a continuous, supportive manner. The recognition of the respective expertise of teachers and lecturers entails that the former would be more involved in university-based teaching, while the latter would be more actively involved in school-based teaching of teacher trainees. This collaborative relationship would also be fruitful in the induction of new teachers during their first year of teaching.

\section{Concluding Comments}

The general feeling of the Faculty staff was that such a values-based approach to the planning of initial teacher education programmes helped clarify goals, and that the articulation of a vision facilitated the development of an increased sense of mission on the part of all. The above framework and material were presented in the form of a discussion document to all staff members, and was adopted unanimously. Consensus was gained largely because the whole exercise had been based on a constructivist approach, with real and concrete concerns being voiced by all and represented faithfully in the overall presentation. Individuals and groups could thus see that their contribution mattered. But they could also recognise the implications of such a contribution to the development of a coherent programme of education. Two key challenges remain. The first is to set up a strong monitoring board-which, in our University's current terminology, would be called a "board of studies"-which ensures that those values are indeed respected by all faculty staff, and that they are felt throughout the overt and covert curricula of the teacher education programmes organised. The second and related challenge is to constantly re-open the issues to debate since values can change, especially when abstract, appealing goals such as "accountability", "constant selfevaluation and (evaluation by peers and by students)", and "option in favour of the 
disadvantaged and non-achieving" have to be translated into concrete activities in the real world. Such challenges and others are not, however, insurmountable, and depend as much on good leadership as on the (re-)interpretation of our professional tasks as a vocation, a calling. Today, perhaps more than ever before, when technocratic, managerial discourse colonizes so effectively so many areas of the life-world, it is crucial that we put democratic values at the heart of our endeavours as educators.

\section{Acknowledgements}

Many members of Faculty staff commented on earlier versions of this paper. Among the most helpful were comments made by Leonard Bezzina, Dr Mary Darmanin (co-ordinator of the Mentoring scheme) and the Dean, Professor Kenneth Wain.

\section{NOTE}

[1] Malta is made up of a group of small islands, two of which are inhabited. The larger island, Malta, has a population of about 325000 , while Gozo's population is about 25000 . The archipelago of islands covers a surface area of about 316 square kilometres. It lies 93 kilometres to the south of Sicily and 290 kilometres to the north of the African coast. Its position in the middle of the Mediterranean and its natural harbours have invited a number of colonial powers-the Carthaginians, the Romans, the Byzantines, the Arabs, the Normans, the various houses of Spain, the French, and finally the British-to take possession of the islands. Malta obtained its political independence in 1964, was declared a republic in 1974, and has recently applied for membership in the European Union. Key events in recent educational history include the introduction of compulsory primary education in 1946 , secondary education for all in 1970, the setting up of vocational schools at the secondary school level in 1972, the raising of school leaving age to 16 years in 1974, and radical reforms at University level (including a Maltese version of the Chinese student-worker scheme) in 1978. A Christian Democrat-type government ousted Labour in 1987, and passed a new Education Act in 1988 which reversed many of the policies of the previous administration. The University of Malta was "re-founded"; increasing emphasis has been placed on post-secondary education, a National Minimum Curriculum was promulgated for students from the Primary school level to the upper Secondary school level, and school councils were set up in an attempt to minimise the traditional and excessive centralisation of the educational system (cf. Sultana, 1992a for critical historical perspectives on the development of the Maltese school system from the early 19th century to the present day). The total government teaching staff complement in 1991 was 3209, of whom 2484 were teachers (1275 females) and 725 were instructors without full teaching qualifications (293 females). 84538 students were in full time education in 1991 , and of these, close to $30 \%$ were in private institutions (Central Office of Statistics, 1993).

Correspondence: R. G. Sultana, Department of Foundation Studies, Faculty of Education, University of Malta, Msida, Malta MSD06. 


\section{REFERENCES}

Abela, A.M. (1991) Transmitting Values in European Malta (Malta, Jesuit Publications and Pontificia Universita' Gregoriana).

Apple, M.W. (1986) Teachers and Texts (New York, Routledge \& Kegan Paul).

Borg, M. \& RIDING, J.R. (1991) Occupational stress and satisfaction in teaching, British Educational Research foumal, 17, pp. 263-281.

Central Office of Statistics (1993) Education Statistics 1990-1991, (Malta, Government Printer).

CoDD, J. (1985) Images of schooling and the discourse of the state, in: J. CoDD, R. HARker \& R. NASH (Eds) Political Issues in New Zealand Education, pp. 23-41 (Massey, Dunmore Press).

DARMANIN, M. (1991) National interests and private interests in policy making, Intermational Studies in Sociology of Education, 1, pp. 59-86.

FARRUGIA, C. \& ATtARD, P. (1989) The Multi-Functional Administrator (London, Commonwealth Secretariat).

FENECH, J. (1992) Curriculum innovation in Malta, Ph.D. thesis, Institute of Education, University of London.

HABERMAS, J. (1971) Knowledge and Human Interests (London, Heinemann).

HrRST, P.H. (1991) Professional preparation and the study of educational situations, in: R. Sultana (Ed.) Themes in Education: A Maltese Reader, pp. xvii-xxv (Malta, Mireva Publications).

Howey, K.R. \& ZIMPHER, N.L. (1989) Profiles of Preservice Teacher Education: Inquiry into the Nature of Programs (Albany, SUNY Press).

KEMMIS, S. (1983) Getting our thinking straight: three views of education, AdVISE, April, pp. 6-8.

Kemmis, S., Cole, P. \& Suggett, D. (1983) Towards the Socially Critical School (Victoria, VISE).

LISTON, D. \& ZEICHNER, K.M. (1991) Teacher Education and the Social Conditions of Schooling (New York, Routledge).

MacDonald, J. (1988) Curriculum, consciousness and social change, in: W. PINAR (Ed.) Contemporary Curriculum Discourses, pp. 156-200 (Scottsdale, AZ, Gorsuch Scarisbrick).

MAYO, P. (1994) Synthesising Freire and Gramsci: possibilities for a theory of transformative adult education, International foumal of Lifelong Education, 13(2), pp. $125-148$.

Musgrave, P. (1984) Three in one or one out of three? AdVISE.

Neave, G. (1992) The Teaching Nation (Oxford, Pergamon).

RoKeach, M. (1973) The Nature of Human Values (New York, Free Press).

RYBA, R. (1992) Common trends in teacher education in European Community countries, Compare, 22(1), pp. 25-39.

Schon, D. (1983) The Reflective Practitioner: How Professionals Think in Action (New York, Basic Books).

SMYTH, J. (1991) Teachers as Collaborative Learners (Milton Keynes, Open University Press).

SPrTer, S. (1994, in press) The Malta Charter of Students' Rights, The Teacher, Summer, pp. 15-16.

Sultana, R.G. (Ed.) (1991) Themes in Education: A Maltese Reader (Malta, Mireva Publications). 
Sultana, R.G. (1992a) Education and National Development: Historical and Critical Perspectives on Vocational Schooling in Malta (Malta, Mireva Publications).

SUlTANA, R.G. (1992b) Teacher power and the struggle for democracy: an educational movement in Malta, International Studies in Sociology of Education, 2(1), pp. 3-22.

TANTI BURLO', E. (1992) Action research project on the handicapped (unpublished report).

VENTURA, F. (1991) Incorporating Environmental Education into the School Curriculum (Malta, Faculty of Education and Foundation for International Studies).

WAIN, K. (1987) Philosophy of Lifelong Education (Kent, Croom Helm).

WILKIN, M. (Ed.) (1992) Mentoring in Schools (London, Kogan Page).

WubBels, T. (1992) Teacher education and the Universities in the Netherlands, European foumal of Teacher Education, 15(3), pp. 157-172.

ZEICHNER, K.M. (1993) Traditions of Practice in U.S. pre-service teacher education programs, Teaching and Teacher Education, 9(1), pp. 1-13. 